\title{
The localization of Catholicism and a personal God-human relation in Chenwu, a Hakka village in South China
}

\author{
Shao Di , Tan Tongxue* \\ Department of Anthropology, School of Sociology and Anthropology, \\ Sun Yat-Sen University, Guangzhou 510275, P.R.China \\ *corresponding author: tantongxue@163.com
}

\begin{abstract}
The author conducted field research on the religious practices and spiritual worlds of Hakka Catholics in Chenwu Village of Heping County, city of Heyuan. The findings show that these Chinese Catholics have localized their religion as influenced by their rural village context. These Catholics follow practices and ideas that are distinct from those of "orthodox" Catholics. An emphasis on a personal relation between God and humans lies at the core of these distinctions.
\end{abstract}

Keywords: Catholicism, localization, religious practice, God-human relation, Fieldwork

\section{Introduction}

As the process of globalization accelerates, the flows of influence between cultures become ever more evident in communities around the globe. When foreign cultural traditions enter a local context, their elements or bearers make certain adjustments or accommodations to become better embedded in the local cultural landscape. This process is called local- ization. James Watson's Golden Arch in the East, a classic on localization, offered a detailed analysis of how the McDonald's Corporation has become localized. ${ }^{[1]}$ Though boasting of its worldwide standardization, the top American fast-food corporation still made respective adjustments to its food or service according to the tastes and habits of its customers and reshaped its meaning in five culturally distinct regions of Asia.

However, localization exists far beyond the sphere of modern economy. It happens in the realm of faiths, too. Religious elements might get transformed or reshaped in terms of functions or meanings after emigrating to different social, economic, and cultural settings. TAN CheeBeng did his research on worship of the traditional Land God among overseas Chinese people in Southeast Asia, and pointed out that Dabogong and Nadugong are regional variations of the traditional Land God that have arisen through the process of localization. ${ }^{[2]}$ Zhang Yudong focused his study on the localization of practices of the religious organization of the overseas Chinese in Southeast Asia. $\mathrm{He}$ argued it was the local context in Southeast Asia that led to a functional 
multiplicity and secularization in many religious organizations. ${ }^{[3][4]}$

In the past three decades, Christianity has been successfully disseminated and has accumulated a much larger population of believers in China, especially in rural areas. As one of the major denominations of Christianity, Catholicism has amassed a large number of rural converts in China. However, these Catholics vary in many ways from the "orthodox" Catholics of the Western world, as the Chinese forms of Catholicism have been localized through certain alterations to accord with the local context. These religious variations can be found in the characteristic practices and understandings of rural Catholics. As the author's recent field research in Chenwu Village indicates, the core of these practices and understandings concerns an attempt to construct a God-human relation of a personal type.

The research was conducted in July, 2013 at Chenwu, a Hakka village which enjoys a 100-year history of Catholic belief, located in Linzhai Town, Heping County, Heyuan City, Guangdong Province in southern China.

\section{Practices: Simplification, Scarcity, and Emphasis}

Religious practices have significant weight in the lives of Catholics. In the context of "orthodox" Catholicism which stresses its institutional characteristic, a Catholic is required to take part in regular rites such as Mass, and to do so under guidance from the clergy. Each follower is also asked to do some daily practices, including Matins, Evensongs and other daily prayers, along with other special yearly practices. However, in the specific context of Chenwu, many of these practices have been simplified or neglected.
The Mass is a compulsory rite that every "orthodox" Catholic is called to attend every Sunday. However, Chenwu Catholics generally attend Mass only three times each year. This obvious distinction from the orthodox regulation is explained by the very infrequent visits of the priests. The village is too distant from the parish church, and the priests working for this parish are too few. Thus, only in rare circumstances do priests visit Chenwu for Mass. As nobody but a priest can take charge of Mass, local Catholics have made an adjustment of their own. They have replaced the complicated, time-consuming Mass with a brief and simple Matin on Sunday. This means that the Matin, which traditionally belongs to the sphere of daily practice, is now counted as something of more importance that is held once a week, somewhat like Mass. Mass, in turn, has become a yet more special practice, similar to having a great seasonal festive occasion. This change also means that Chenwu Catholics try to get close to God and upgrade themselves in a religious way in the absence of the clergy, which is not permitted according to institutional "orthodoxy".

Another innovation by Chenwu Catholics is to occasionally substitute Matin with Evensong on market days, so that their attendance at the bazaar in town will not be impeded. Also, the group attending Matin at the church includes only a small proportion of those who call themselves Catholics. Many Catholics practice their Matin at home, or else do nothing on Sunday morning.

With Matin or Evensong changing from daily to weekly practice, the remaining daily practices performed by Chenwu Catholics mainly include praying, reading Catholic classics, singing hymns, or obeying religious commandments. Through observation and interviews, the author found that 
Chenwu Catholics have various approaches to these practices. In general, reading classics and singing hymns are ignored by most Catholics for at least two reasons. The meanings of reading and singing are not recognized by the Catholics here. Many of the believers are always busy doing agricultural production or other work. Therefore, they spend no time on things that they see as meaningless business. As for obeying religious commandments, rural Catholics vary in their behavior. Some Catholics in Chenwu recognize the necessity of obeying commandments, and claim they never break their vows. Others, however, feel that it is understandable and forgivable to take part in gambling occasionally.

Despite their many simplifications and omissions, most local Catholics stress the practice of praying. A considerable number of believers pray to God every day. Others may not do this every day, but still pray about important matters. More significantly, most of those who regard themselves as Catholics take praying as the distinguishing mark of being a Catholic. Their purposes in praying are always identical. They pray for their safety and well-being, or the realization of certain wishes.

Special religious practices of Catholicism include rituals around holidays or rites of passage in life, such as funerals and other rites of the faith including baptism, confirmation, extreme unction and so forth. In Chenwu, however, these special rites are commonly ignored or greatly simplified and transformed. Always lacking in priests to take charge of these rites, the local Catholics place little emphasis on these practices. It is quite rare for them to have someone baptized or to take the Eucharist in the presence of a priest. As for local funerals of Catholics, these basically remain traditional events, although mixed with some ideas or customs of Christianity. For example, burning incense, which is often related to worshiping other gods, is forbidden at Catholic funerals, and collective praying for the dead is always observed. In terms of religious holidays, Christmas Day is the only holiday that Chenwu Catholics celebrate, as local believers have little knowledge of other holidays. However, in considering the performances that occur and the many spectators who are not Catholics at the Christmas celebration activities, it is justifiable to regard this festival as secular entertainment event for the whole village.

From the introduction given above, it is reasonable to draw the conclusion that the religious practices of local Catholics are rather different from those of "orthodox" Catholicism. In Chenwu, local Catholics have simplified or transformed many practices such as Mass, special rites, and holiday celebrations through local initiatives, passive neglect, or lack of instruction. Institutionalism stressing the presence of priests was lost here. However, the practice of praying is emphasized by almost all believers here.

\section{Ideas: Diversified and Flexible Re- ligious Identification Criteria}

The above-mentioned description about the religious practices of local Catholics tends to be general, while the specific condition of individuals may vary a lot in terms of how much they emphasize, neglect or simplify the respective practices. This diversity of the religious practices, together with the individual flexibility, result in rather diversified and flexible identification criteria among Chenwu Catholics and non-Catholics in the local context.

The answer to the question "Who can be counted as a Catholic" is uncertain and largely contingent on answerers them- 
selves as well as the circumstances they are in. The most popular criterion is in some circumstances accepted by all the Catholics and non-Catholic in Chenwu and it is two-fold. First of all, a qualified Catholic must pray to God. In Chenwu, praying to God is generally a label of being a Catholic. Secondly, a Catholic can only worship God, as is asked in the Bible. Actually there exist only a few people who worship God and other local divinities together and in most people's opinion, they can be identified as Catholics in no way. By this very inclusive criterion, villagers who pray to God, frequently or occasionally, are counted as Catholics, even though a number of them might rarely visit church, or hardly read classical, or break the commandment in a frequent way. Some Chenwu "Catholics" frankly confessed that they did try their fortune by attending the Mark-Six, an illegal lottery or gambling game which is popular in most rural areas of Guangdong. As a gambler "Catholic" said, "It's just a sort of entertainment, and you never lose much even when you are in a constant bad luck." When talking about this to the author, they show no signs of confession, while claiming firmly that they are Catholics, because they pray, and only pray to God.

Another criterion is that the people who are regarded as Catholics must come to church for Matin and the infrequent Mass once at least within a certain period of time. The very length of the period is various among different people's opinion. It can be "a few weeks" or "a few months", even as long as a year sometimes. This criterion stress the significance of going to church, mostly held by the Catholics who attend the Matin on Sunday frequently. They see going to church as a means to show their true faith (in contrast with those who hardly turn up in the church, but claim themselves Catholics). However, practically speaking this crite- rion is still an inclusive one. It counts many people as Catholics who have a faith in God, but lack opportunities for visiting Church frequently. Most of these people are migrant workers in large cities, who have no chance to visit churches whole year round except the occasionally return to their home place. Apart from this fact, most of the informants told author it is nearly impossible to attend the Matin every Sunday during the busy farming season. Nonetheless, this "tolerant" criterion also sees many people as Catholics who actually show no signs of Catholicism in their lives besides visiting the church occasionally. "See, I take you as a believer, too", an old lady attending the Matin said to the author these words when conducting his research in the church one day.

A less popular, but much stricter criterion is sometimes held by those "devout" Catholics only when they feel it is time to show their "superiority" in terms of being Catholics. As a minority of the local Catholics, these believers try their best to attend the Matin or Evensong every Sunday, pray to God frequently, stick to commandments, sing hymns and read classical (though they may not have a clear idea what they are reading about). These "devout" Catholics are proud of their dedication and see those who fail to complete every practice as "false" believers. They believe that more enthusiastic to the matters relevant to God, closer they will be to God and their zeal for these matters is somehow a stronger guarantee for God's better response to their prayers. Though very passionate for Catholicism, they show little interests in Catholic doctrines, or theological knowledge and they fail to have a clear picture about the Roman Catholic Church and Pope. This might be explained partly by the infrequent visit of the priests but it seems what the "devout" Catholics care the most is 
always how to build up a close bond with God directly with prayers.

There are some "marginal" believers who show an ambiguous attitude to Catholicism, quite in contrast to those enthusiastic ones. These "marginal" believers would select different criteria in different situations. As a foreign faith, Catholicism is sometimes repelled and depicted as a hypocritical faith by people in the neighboring villages of Chenwu. In this circumstance, the "marginal" Catholics might apply the stricter criterion in order to render themselves non-Catholics to elude some potential troubles. However, when in a situation which welcomes Catholics, they might switch to the two inclusive criteria to manifest their belongings to the group of Catholics to enjoy some possible benefits. It is easy to find the existence of a strategy of these ambiguous believers here in the choice of certain criterion according to the specific context.

\section{The Core: Personalized God- human Relationship}

When conducting fieldwork research in Chenwu, the author discovered that the majority of "devout" Catholics in the village are elderly females. Most of these women have had a painful past, as they revealed in their interviews. Some were chosen as child brides, had an unpleasant life after marriage, suffered from severe diseases, or lived a lonely life without much material or spiritual support from friends or relatives. These elder women have commonly lacked sufficient support from the community and have faced difficulty or hardship living on their own. Many have felt that the circumstances of their lives are hard to control. Therefore, they have longed for a strong source of support with which they could truly master and better their lives. God, the socalled omnipotent and omnipresent creator and ruler of all, satisfies their intense longing. By praying to God, these elderly ladies depend on God's response to master their lives or to make their lives less painful and hazardous. It was easy for the author to collect various narratives concerning miracles or wonders from Chenwu Catholics, mainly focusing on how God saved someone's life in a moment of great danger.

As has been stated, local Catholics place much emphasis on the practice of praying. The reason for this, according to the believers, is that only through "talking to God" can they face and communicate to God directly. The more frequently and reverently they pray, the more strongly they feel that God will guide and protect them or realize their wishes. Other practices such as reading the classics or singing hymns offer no such precious opportunity. Thus, these indirect means of reaching God are simplified or ignored by the majority of the local believers. As for those "devout" Catholics who still emphasize the importance of these indirect means, they do this not because they like these practices but to have a strong wish to build up a close relation with God, a wish actually shared almost by every believer.

Therefore based on the data collected from the field research, the author argues that local Catholics attach great importance to constructing and maintaining a personal relationship between God and themselves. In their understanding, God is like a powerful friend to all believers. The believers feel the existence of God, worship and pray to Him. They trust that in return, God will grant them security, make their lives less painful, or realize their wishes. In response to such support, the believers worship and pray to God even more. This understanding of a personal, direct Godhuman relationship differs to some extent from that of the "orthodox" faith. 
Traditional institutional Catholicism stresses mediation or guidance from the clergy in the communication between God and humans, as God cannot simply be met through an individual's faith. It is a characteristic of Catholicism that the Church and its clergy enjoy high status and esteem. However, in Chenwu, which is far from where the clergy live and work, priests are not expected to visit frequently. This fact, as noted before, has resulted in a simplification or lack of many religious practices, but also an emphasis on praying, which needs no presence of priests. This situation tends to strengthen the maintenance of a personal God-human relation that characterizes the rural Catholics in Chenwu.

There are other faiths in Chenwu in addition to Catholicism, such as Buddhism or faith in Guandi, Mazu, Guanyin, and other divinities. These types of Chinese traditional faith also focus on a personal, direct God-human relation. As a matter of fact, nearly all of these divinities have a "previous" life of being a person with some uncommon experiences or merits. This fact sometimes renders these divinities more like uncommon people rather than typical divinities. When believers of these faiths have certain wishes to realize or secure, such as a wish to escape danger, they visit their temples or other divine locations to engage in pious prayer (хиуиаn). When their wishes finally come true, the believers regard it as an outcome of divine power, and thus show their gratitude to the divinities or powerful immortals through a rewarding visit (huanyuan). The whole process is like practicing an exchange with a person. In all likelihood, the personal God-human relation of the Chenwu Catholics is largely influenced by the context in which this type of God-human relation is popular. In a sense, the faith in Catholicism is somehow a variation from these traditional beliefs. The object of worship alters, but still remains the personal, direct Godhuman relationship.

However, there is still an obvious distinction between local Catholics and believers in other local faiths. The Catholics retain a firm belief in monotheism, whereas the other believers either do not have this belief or have no restrictions on deity worship at all. NonCatholic believers can worship or pray to several divinities or immortals at the same time, or pay tribute to certain divinities or immortals according to their specific wishes. For example, a worshiper of Guandi might pray to Guanyin when he or she longs for a son, as it is believed that Guanyin will send her worshipers a son. Persistence in monotheism makes the Chenwu Catholics rather distinct in the local context, and devotion to a single God has become their basic feature of self-identification. Hence, despite localization, Chenwu Catholics still preserve certain "orthodox" traditions that mark them as distinct from other local people.

\section{Conclusion: Localization with vari- ations and persistence}

When foreign cultural elements enter a local context of complex social traditions, the foreign elements or their bearers tend to undergo alterations or adjustments so that they can better relate to the local cultural context. This theory of localization is illustrated by the experience of Catholics in Chenwu.

It is justifiable to say that Catholicism, as a religion foreign to China, has gone through certain adjustments since entering the Chinese rural areas, as seen in the modified religious practices and diversified identification criteria of the Chenwu Catholics. The modification of Catholicism involves simplification, negligence, or shifts in emphasis on religious practices. In Chenwu, the weekly Mass has been 
simplified to a practice of Matin or Evensong. Reading the classics, singing hymns, and obeying commandments have been ignored, at least to some extent. Praying is the only practice that is stressed, as it offers a chance for believers to communicate with God directly and personally. Having much to do wtih the diversified identification criteria, local Catholics' attitudes toward religious practices come from the core of their religious understanding - that a personal relationship between God and humans, without any interference from priests, is the most important aspect. This understanding is different from that of "orthodox" Catholicism, and it is an outcome of the local context. First of all, Chenwu is far from the center of the parish where the priests are, and priests rarely come to the village. These factors help to explain the "unorthodox" understandings of the local Catholics. Second, the local context of personal relations between God and human makes it possible for Chenwu Catholics to hold this idea naturally.

However, going through a process of localization does not mean that the foreign cultural elements are completely changed into local elements. In fact, transnational religious spreading often gives rise to a phenomenon of hybridity, a co-existence of and an interaction between the local and foreign cultural elements rather than the simple disappearance of all foreign characteristics. The hybridized or creolized religious beliefs and practices are manifestations of a convergence of "local" and "global". This is certainly true in the case of the Chenwu, where the foreign elements still preserve some of their features. Although the Chenwu Catholics have changed many "orthodox" and institutional practices, their persistence in monotheism and emphasis on praying are preserved in this special local context, even if the reason for such emphasis might be different from that found in other places.

\section{References}

[1] James Watson, Golden Arches East: McDonald's in East Asia. Stanford: Stanford University Press, pp. 35-38, 1997.

[2] TAN Chee-Beng, "The Land God of the Chinese in Southeast Asia and Sacred Relic Worship" [A]. Journal of Guangxi University for Nationalities, (1), pp. 16-24, 2001 (in Chinese).

[3] Zhang Yudong, "The Formation, Characteristics and Developing Trends of the Traditional Religions of the Overseas Chinese People in Southeast Asia" [J]. Studies in World Religions, (1), pp. 98-108, 2005 (in Chinese).

[4] Zhang Yudong, "The Secularization and Anti-secularization of the Traditional Religions of the Chinese Overseas People, Based on a Study in Chinese Overseas in Southeast Asia" [J]. Religious Studies, (4), pp.117-120, 2004(in Chinese).

[5] Compilation Committee of Hepin County Annals, Hepin County Annals. Guangzhou: People's Press of Guangdong, pp.300-301,1998(in Chinese). 